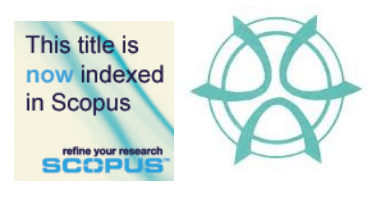

PLANNING MALAYSIA:

Journal of the Malaysian Institute of Planners

VOLUME 16 ISSUE 1 (2018), Page 163 - 172

\title{
DEVELOPMENT OF URBAN MARKET SPATIAL FOR HIGHEST AND BEST USE OF LAND PRODUCTIVITY AND SUSTAINABILITY
}

\author{
Christiono Utomo ${ }^{1}$, Yani Rahmawati ${ }^{2} \&$ Iman Krestawan $^{3}$ \\ ${ }^{1,3}$ Faculty of Civil Engineering and Planning \\ INSTITUT TEKNOLOGI SEPULUH NOPEMBER, INDONESIA \\ ${ }^{2}$ Faculty of Civil and Environmental Engineering \\ UNIVERSITI TEKNOLOGI PETRONAS, MALAYSIA
}

\begin{abstract}
No less than $40 \%$ of around 70 traditional retail markets in Surabaya are located in the downtown area where the economic value of the location is high, but not being optimally utilized. Sustainable planning can be achieved if the area is not only able to stand and grow by itself but also contributes to the economic growth of the region and the surrounding trade. Based on its potential, urban land use is principally needed to be analysed on its capability in producing highest property value. This research develops adaptive and collaborative concepts on spatial configuration design and market economy value in urban area. It is found to be the best regional planning concept to support sustainable economic achievement. It also has the capability in minimizing failure of market development in urban areas as well as supporting success in structuring the city. Triangulation method was applied through qualitative and quantitative approaches, and using Highest and Best Use (HBU) analysis technique. The analysis began with an explorative study to explore alternatives of land use, which was then followed by a 5 -stages analysis including determination of alternative use, regulatory compliance and permits, possibility and affordability of construction, financial feasibility, and maximum productivity of land.
\end{abstract}

Keyword: Urban, market, highest and best use, productivity, sustainability 
Christiono Utomo, Yani Rahmawati \& Iman Krestawan

Development of Urban Market Spatial for Highest and Best Use of Land Productivity and Sustainability

\section{INTRODUCTION}

The scope of market services has a significant impact on the reduction in the quality of space and the carrying capacity of the surrounding environment (Utomo, Rahmawati, Suhartono, \& Negoro, 2015). These impacts, among others, are caused by the increasing number of traders and agricultural commodities that are not unloaded at designated space. These give rise to congestion in the area (Reed \& Kleynhans, 2011). This situation has been partially addressed by the Surabaya City Government in 1980s by standardizing the markets' design and modernization that was oriented on the supplying more stalls. Nevertheless, the problem remains. Because of the behaviour and character of traders and consumers in the market location, large number of stalls remain empty while traders continue to operate by the roadside.

The existence of traditional urban market in Surabaya plays an important role as part of the logistics distribution network in Surabaya, especially to supply food items to the citizens. Therefore, it may be unwise for city government to relocate the market out of urban area in order to solve its associated problems. A better solution would be to revitalise the market. The goal of revitalization is to increase the value of land and buildings as well as to solve problems associated with urban market in order to support the development of the region and the development of the property sector in the region. A HBU analysis (Rattermann, 2008) was used to decide the best option for traditional market development in urban area.

\section{LITERATURE REVIEW}

One approach to determine the use of urban land is by looking at its highest and best use (HBU). The HBU is defined as the possible legal and logical use of an empty or upgraded property, which physically, reasonably, and financially feasible allowing it to deliver the highest value (The Appraisal Institute, 2001). HBU is a concept of appraisal that can be applied to land or building which is usually interpreted as land use which will maximize the wealth of the owner through the most profitable use of the land (Grissom, 1983).

The highest and best use rests on marketability analysis to identify the most competitive, most profitable use of the land or property. This use is shaped by a competitive boost in the area where the property is located and provides the foundation for a thorough investigation of the property position in the minds of market participants. Understanding market behaviour developed through market analysis is essential for the highest and best use concept.

The intended properties in this study were land and/or buildings. A building is defined as a technical construction planted or fixed permanently on land and/or water. Properties can be classified in five groups, which are: the first is residential property consisting of two types, which are: single family homes (freestanding homes, town homes) and multifamily homes (apartments, 
PLANNING MALAYSIA

Journal of the Malaysia Institute of Planners (2018)

condominiums, cooperatives, planned unit developments); the second is commercial property, which consists of office property, where the user of the building provides trade and services; the third is retail property, where the user of the building provides traded goods; the fourth is industrial property, that includes all land or facilities used for industrial activities including warehousing, consisting of industrial real estate, light manufacturing or assembly, storage or warehouse/ office/distribution; the fifth is special purpose property, that includes hotels, motels, club houses, resorts, cinemas, schools, campuses, government offices, places of worship (Kyle, 2005).

Land and building is one of the most popular areas of investment due to its ability to increase in value. The value generated is likely to increase over the years rather than decrease. In respect of asset value, land mastery is an essential part in the government's balance of capital. In this regard, determining land use is an important factor in good governance and it is important to determine the right added value due to planning in addition to the land's actual value. A land use is the arrangement on how a land is supposed or not supposed to be used, so it can be inferred that a used land means a land that has a specific purpose/designation and is owned by a particular individual or institutions. In land use arrangement, one must make the best choices and decisions to use the land for a particular purpose that can be achieved.

Land use is the use of space both above and below the ground. So the use of land can be a projection of the space function, including the distribution of space that indicates the function or activity of the city concerned. It is closely related to the system of inter-human activity up to the institutional level i.e. individuals, households, companies, and each has different interests (Chapin and Kaiser, 1979).

\section{METHODOLOGY}

This research uses qualitative and quantitative methods. Quantitative method was applied by implementing the principle of highest and best use (HBU). The determination of alternative building functions was done through stakeholder analysis. The analysis began with the determination of key stakeholders, whom were representatives of property management, Surabaya City Government, urban planning experts and 20 traders in traditional market who were sampled randomly. The quantitative method was applied for legal and physical analysis to get the maximum capacity of building. The quantitative approach was also applied for financial analysis using cash flow, market value, and productivity analysis.HBU process is usually done in sequence. Only alternative determination steps can be before or at the time of completion of legal receipts that are highly dependent on the decision whether illegal use is considered (Rahmawati, Utomo, Anwar, Setijanti, \& Nurcahyo, 2014). The maximum productivity of a land is the use that results in the highest value of the difference 
Christiono Utomo, Yani Rahmawati \& Iman Krestawan

Development of Urban Market Spatial for Highest and Best Use of Land Productivity and Sustainability

between the pre-use value and after use, or the highest and consistent residual value. The value of land is obtained by the market capitalization rate. Revenue earned from development is subtracted from net income from total property. The remaining income is land residual technique. With this method, the market value of the land can be known if the value of the relatively new building market can be known with certainty.

Some methods of measuring the value of buildings are by cost approach and market data approach in the context of cost estimation. The value of the property can be obtained from NOI (Net Operating Income) or NOI divided by the rate of capitalization obtained from the aggregation of expectations against the rate of return. Finally the value of the land can be obtained by subtracting the property value by the value of the building.

\section{URBAN MARKET SPATIAL: A CASE STUDY}

Keputran Market is a traditional urban market that plays an important role as part of the distribution network of logistics in the city, especially for the fulfilment of food needs of the citizens of the city. Due to its importance, relocating it to the suburb may not be the best solution to its associated problems. Hence, it should be revitalized. Due to the age of the building, it was in feasible conditions to be used. The building functions was not optimal when compared with its strategic location. Figure 1 shows the location of Keputran Market, the condition inside building and its environments.
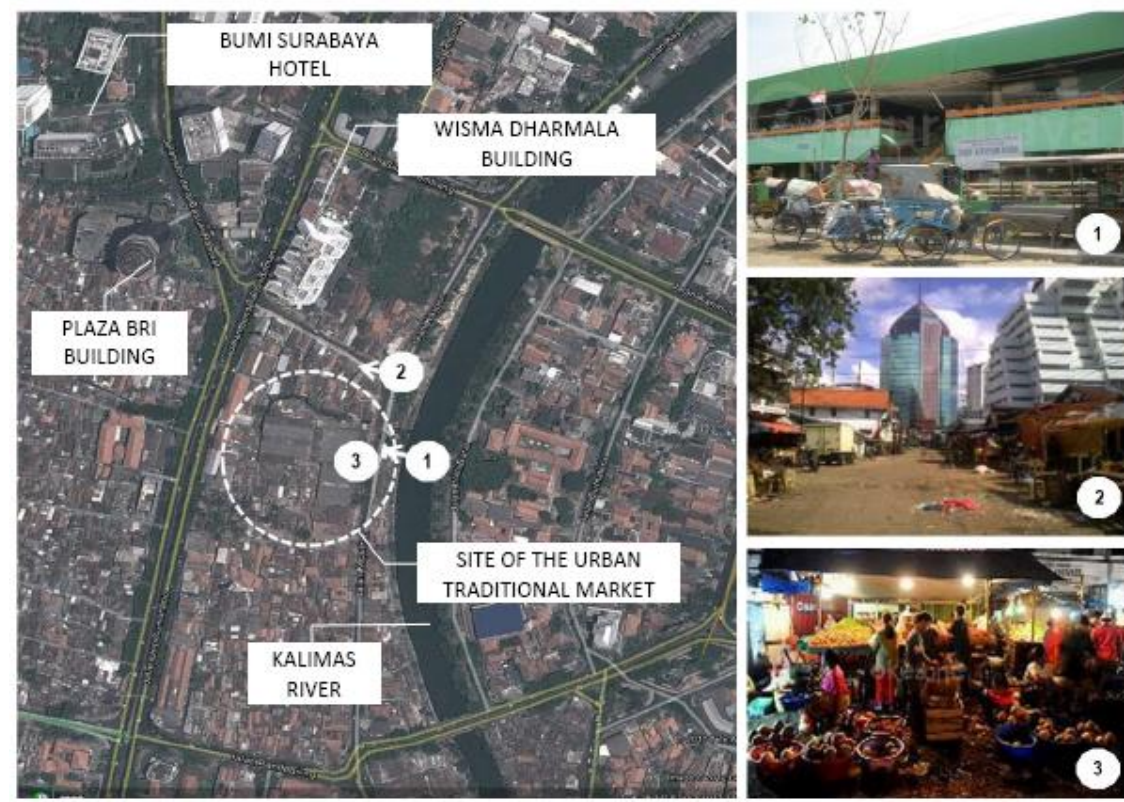

Figure 1: Keputran urban traditional market 
PLANNING MALAYSIA

Journal of the Malaysia Institute of Planners (2018)

Keputran Market is located in Keputran, Surabaya with a land area of $\pm 7537.9 \mathrm{~m}^{2}$ and a floor area of $\pm 8696 \mathrm{~m}^{2}$. It has 1,621 stall units, with total number of registered traders was 777. Land use in the Keputran area is predominantly residential, commercial and service activities, and public services (Table 1).

Table 1: Condition of existing spatial use pattern of Keputran area

\begin{tabular}{llll}
\hline No & Spatial Pattern & Area $(\mathbf{H a})$ & $\mathbf{( \% )}$ \\
\hline 1 & Public facilities & 3.42 & 4.54 \\
2 & Residential & 21.91 & 29.09 \\
3 & Trade and services & 11.03 & 14.64 \\
4 & Open space & 2.00 & 2.65 \\
5 & Cemetery & 0.25 & 0.33 \\
6 & Others & 37.22 & 49.41 \\
\hline & Total & $\mathbf{7 5 . 8 3}$ & $\mathbf{1 0 0}$ \\
\hline
\end{tabular}

Keputran is a developing area. In addition to the existing urban facilities neighbouring the Keputran Market, there is also a plan to build a super block, multilevel, mix-use facility that utilizes the land adjacent to Keputran Market. Keputran Market development plan is directed to adjust the growth of the surrounding area. Both in terms of linkages to traditional market activities as well as in terms of providing urban support facilities. Meanwhile, Table 2 presents the building and site intensity of the Keputran Market.

Table 2: Building and site intensity of Keputran Market

\begin{tabular}{|c|c|c|}
\hline No & Aspect & Description \\
\hline 1 & $\begin{array}{l}\text { Micro site } \\
\text { zoning }\end{array}$ & $\begin{array}{l}\text { Keputran market is a Class } 1 \text { market, which a land area of } \\
\pm 8,696 \mathrm{~m}^{2} \text {. }\end{array}$ \\
\hline 2 & $\begin{array}{l}\text { Building } \\
\text { coefficient }\end{array}$ & $\begin{array}{l}\text { The building coefficient was in the range of } 70 \% \text {. With the } \\
\text { density level and attendance of stand facility reached } 50 \% \text {. }\end{array}$ \\
\hline 3 & $\begin{array}{l}\text { Building floor } \\
\text { coefficient }\end{array}$ & $\begin{array}{l}\text { Keputran Market building floor coefficient reached } 140 \% \text { or } \\
\text { equivalent to two floors. }\end{array}$ \\
\hline 4 & $\begin{array}{l}\text { Green } \\
\text { coefficient }\end{array}$ & $\begin{array}{l}\text { Green coefficient in the Keputran Market environment was } \\
\text { not taken into account in land development. The green area } \\
\text { was realized in the form of circulation and parking. }\end{array}$ \\
\hline 5 & $\begin{array}{l}\text { Border } \\
\text { line/Building } \\
\text { setback }\end{array}$ & 10 meters (front), 5 - 8 meters (side). \\
\hline 6 & Occupancy rate & $\begin{array}{l}\text { From } 1,621 \text { total stalls, only } 1,414 \text { units were active, while } \\
\text { the remaining } 237 \text { units were empty. The occupancy rate of } \\
1^{\text {st }} \text { floor was } 98 \% \text {, while the } 2^{\text {nd }} \text { floor was } 35 \% \text {. }\end{array}$ \\
\hline
\end{tabular}


Christiono Utomo, Yani Rahmawati \& Iman Krestawan

Development of Urban Market Spatial for Highest and Best Use of Land Productivity and Sustainability

\section{RESULT AND DISCUSSION}

The analysis involved two stages, which were determination of development alternatives through stakeholder analysis and stage of HBU analysis. The analysis phase to determine land use alternatives was done through interviews and questionnaire survey among the stakeholders who were directly involved in the utilization of Keputran Market land. Furthermore, to determine the alternative that will provide the highest and most economically profitable land market value, each of the alternatives was tested using the four criteria of HBU, which are legally permissible, physically possible, financially feasible, and maximally productive.

\section{Result and Discussion 1: Stakeholder Analysis}

Stakeholders are people, groups or entities that are impacted by a programme intervention (either positive or negative) or those that can influence the outcome of the intervention. Stakeholder analysis is an important tool in understanding the social and multi-social context of a programme, project, or policy. In this study, stakeholder analysis was undertaken with the aim to determine the selection of alternative development in accordance with the main activities of Keputran Market, which can provide basic information about (1) stakeholders who will be affected by a programme, (2) stakeholders that may affect the programme, (3) which individual or group needs to be involved in the programme, and (4) how and whose capacity needs to be built to empower them in participating in the programme.

The stakeholders were the Government (officials) as the policy makers as well as the owner of the traditional market, property managers as experts in providing analysis related to the asset development plan, urban planners as experts in giving consideration to the selection of alternative development plans and, traders as actors who were directly involved and will be affected by the development of Keputran Market.

From stakeholder analysis, it was found that stakeholders have different views and preferences regarding the market development (Table 3). Property managers, the Government and urban planners have influence and interest to traditional market development plan. And the rest of them, stakeholders who actively engaged in traditional market (Rahmawati et al, 2014), have interest to choose alternative to develop.

Table 3: Stakeholders preferences of alternatives

\begin{tabular}{lllcccc}
\hline & & \multicolumn{4}{c}{ Stakeholders } \\
\cline { 3 - 6 } No & Alternatives & Traders & $\begin{array}{l}\text { Property } \\
\text { managers }\end{array}$ & $\begin{array}{l}\text { Urban } \\
\text { planners }\end{array}$ & $\begin{array}{l}\text { Government } \\
\text { officials }\end{array}$ & Score \\
\hline 1 & Market diversification & Yes & Yes & Yes & Yes & 4 \\
2 & Parking building & Yes & Yes & No & Yes & 3 \\
& & & & & &
\end{tabular}




\begin{tabular}{ll} 
Yes & Yes \\
No & No \\
No & No \\
Yes & No \\
\hline
\end{tabular}

$\begin{array}{lcl}\text { No } & \text { Yes } & 3 \\ \text { Yes } & \text { No } & 1 \\ \text { Yes } & \text { No } & 1 \\ \text { No } & \text { No } & 1\end{array}$

\section{Result and Discussion 2: Highest and Best Use}

Stage 1: Legal Acceptance Analysis

The legal acceptance analysis evaluates feasibility of alternatives based on the provisions of prevailing regulations of an area. For this study, the legal acceptance analysis was performed against several legal criteria, which were private restriction, zoning, building codes, and environmental regulation. Table 4 shows the result of the analysis.

Table 4: Results of legal acceptance analysis

\begin{tabular}{llccc}
\hline No & Legal aspect criteria & \multicolumn{3}{c}{ Alternatives } \\
\cline { 3 - 5 } & & $\begin{array}{c}\text { Market and } \\
\text { diversification }\end{array}$ & $\begin{array}{c}\text { Market and } \\
\text { affordable } \\
\text { housing }\end{array}$ & $\begin{array}{c}\text { Market and } \\
\text { building } \\
\text { parking }\end{array}$ \\
\hline 1 & Private restriction & Allowed & Allowed & Allowed \\
2 & Zoning & Allowed & Allowed & Allowed \\
3 & Building Codes & Allowed & Allowed & Allowed \\
4 & Environmental regulation & Allowed & Allowed & Allowed \\
\hline
\end{tabular}

Stage 2: Physical Acceptance Analysis

The selection process for alternative land use considers the physical characteristics of the site. This physical characteristics will significantly influence the highest and best use of land. A piece of land may reach its highest and best use on a particular usage alternative but not suitable for other alternative uses. The ranges of physical characteristics that must be considered include size, shape, terrain, and the availability and capacity of public facilities.

In the case of the study area, with a building coefficient of $60 \%$ and a building floor coefficient of $300 \%$ or equivalent to 5 floors, it was calculated that the total area of the effective building floor area allowable would be $19,770.39 \mathrm{~m} 2$, with market floor area of $9,478.23 \mathrm{~m}^{2}$, leaving $10,292.16 \mathrm{~m}^{2}$ for other alternative uses. Table 5 shows that based on the physical acceptance analysis, any of the three alternatives can be developed. 
Christiono Utomo, Yani Rahmawati \& Iman Krestawan

Development of Urban Market Spatial for Highest and Best Use of Land Productivity and Sustainability

Table 5: Results of physical acceptance analysis

\begin{tabular}{llccc}
\hline No & Physical aspect criteria & \multicolumn{3}{c}{ Alternatives } \\
\cline { 3 - 5 } & $\begin{array}{c}\text { Market and } \\
\text { diversification }\end{array}$ & $\begin{array}{c}\text { Market and } \\
\text { affordable } \\
\text { housing }\end{array}$ & $\begin{array}{c}\text { Market and } \\
\text { building } \\
\text { parking }\end{array}$ \\
\hline 1 & $\begin{array}{l}\text { Size, shape, contour of } \\
\text { the land }\end{array}$ & Possible & Possible & Possible \\
2 & $\begin{array}{l}\text { Accessibility and public } \\
\text { facilities }\end{array}$ & Possible & Possible & Possible \\
\hline
\end{tabular}

Stage 3: Financial Acceptance Analysis

Financial acceptance analysis looks at the investment by taking into account the cost of land preparation, construction costs (building costs and fixed equipment costs), professional service fees, administration fees, and other costs. The financial acceptance analysis was based on $10.75 \%$ capitalization rate of loan, and that the basic lending rate would remain the same, the results are as presented in Table 6.

Table 6: Results of financial acceptance analysis

\begin{tabular}{lccccc}
\hline \multirow{2}{*}{ Alternatives } & \multicolumn{3}{c}{ Criteria of Capital Budgeting } & Priorities & Feasibility \\
\cline { 2 - 4 } & BCR & NPV & IRR & & \\
\hline $\begin{array}{l}\text { Market and } \\
\text { diversification }\end{array}$ & 2.41 & $\begin{array}{c}\text { 0.5 Million } \\
\text { USD }\end{array}$ & $28 \%$ & $1^{\text {st }}$ & Feasible \\
$\begin{array}{l}\text { Market and } \\
\text { affordable housing }\end{array}$ & 1.87 & $\begin{array}{c}\text { 1.4 Million } \\
\text { USD }\end{array}$ & $22 \%$ & $2^{\text {nd }}$ & Feasible \\
$\begin{array}{l}\text { Market and building } \\
\text { parking }\end{array}$ & 1.59 & $\begin{array}{c}\text { 2.3 Million } \\
\text { USD }\end{array}$ & $19 \%$ & $3^{\text {rd }}$ & Feasible \\
\hline
\end{tabular}

Stage 4: Maximum Productivity Analysis

The maximum productivity analysis was used to measure how high the value of land would be after development. Using the residual value method, the value of land was determined based on gross development value, total development value, and minimum profit requirements. The productivity of land was estimated at approximately $60 \%-160 \%$ higher than traditional market without development.

The basis of the financial calculation was investment rate of return based on the financing source. The source were equity (30\%) and loan (70\%), while the costs of capital were $12.77 \%$ for equity and $10.75 \%$ for loan. Using weighted average cost of capital (WACC) method, the minimum attractive rate of return (MARR) investment was calculated at $11.36 \%$.

Building capitalization rates were used to determine the estimated market value of the land as a benchmark for maximum productivity. If the market value of land after development was higher than the market value of land without 
PLANNING MALAYSIA

Journal of the Malaysia Institute of Planners (2018)

development, then the mix-use building is feasible to be developed. Based on the results of the maximum productivity analysis, there were two mix-used alternatives that have a high level of land productivity. These alternatives were the diversification of market businesses and the addition of parking building. Table 7 presents the calculation of the estimated market value of land for each mix-use development. The results show that the highest property value (USD $2,094 / \mathrm{m}^{2}$ would be attained by the development of diversified market businesses.

Table 7: Estimated property value

\begin{tabular}{|c|c|c|c|c|}
\hline \multirow[b]{2}{*}{ No } & \multirow[b]{2}{*}{ Variables } & \multicolumn{3}{|c|}{ Mix-use Alternatives of Market Building } \\
\hline & & $\begin{array}{c}\text { Diversification of } \\
\text { market business }\end{array}$ & $\begin{array}{c}\text { Rental affordable } \\
\text { housing }\end{array}$ & $\begin{array}{l}\text { Parking } \\
\text { building }\end{array}$ \\
\hline A & Market value (building) & USD $13,038,549$ & USD $125,26,169$ & USD $12,268,526$ \\
\hline B & $\begin{array}{l}\text { Capitalization rate } \\
\text { (building) }\end{array}$ & $11 \%$ & $11 \%$ & $11 \%$ \\
\hline $\mathrm{C}$ & $\begin{array}{l}\text { Net income (building) } \\
=(\mathrm{A}) \times(\mathrm{B})\end{array}$ & USD $1,434,240$ & USD $1,377,878$ & USD $1,349,537$ \\
\hline $\mathrm{D}$ & $\begin{array}{l}\text { Total floor area } \\
\text { (planned) }\end{array}$ & $29,837.83 \mathrm{~m}^{2}$ & $26,663.14 \mathrm{~m}^{2}$ & $31,215.17 \mathrm{~m}^{2}$ \\
\hline $\mathrm{E}$ & $\begin{array}{l}\text { Market value } \\
\text { (building) } / \mathrm{m}^{2}=(\mathrm{C}) /(\mathrm{D})\end{array}$ & $4,806 \mathrm{USD} / \mathrm{m}^{2}$ & $5,167 \mathrm{USD} / \mathrm{m}^{2}$ & $4,323 \mathrm{USD} / \mathrm{m}^{2}$ \\
\hline $\mathrm{F}$ & $\begin{array}{l}\text { Net income (property) } \\
\text { after tax }\end{array}$ & USD $3,187,356$ & USD $2,429,471$ & USD $1,883,832$ \\
\hline G & $\begin{array}{l}\text { Net income (land) } \\
=(\mathrm{F})-(\mathrm{C})\end{array}$ & USD $17,531.15$ & USD $10,515.93$ & USD 5,342.94 \\
\hline $\mathrm{H}$ & $\begin{array}{l}\text { Capitalization rate } \\
\text { (land) }\end{array}$ & $13 \%$ & $13 \%$ & $13 \%$ \\
\hline I & $\begin{array}{l}\text { Market value (land) } \\
=(\mathrm{G}) /(\mathrm{H})\end{array}$ & USD $13,485,505$ & USD $8,089,179$ & USD $4,109,958$ \\
\hline $\mathrm{J}$ & $\begin{array}{l}\text { Total floor area } \\
\text { (effective) }\end{array}$ & $6,590.13 \mathrm{~m}^{2}$ & $6,590.13 \mathrm{~m}^{2}$ & $6,590.13 \mathrm{~m}^{2}$ \\
\hline K & $\begin{array}{l}\text { Market value (land) } / \mathrm{m}^{2} \\
=(\mathrm{I}) /(\mathrm{J})\end{array}$ & USD 2,046 & USD 1,227 & USD 623 \\
\hline $\mathrm{L}$ & $\begin{array}{l}\text { Property value } / \mathrm{m}^{2} \\
=(\mathrm{K})+(\mathrm{E})\end{array}$ & USD 2,094 & USD 1,279 & USD 666 \\
\hline
\end{tabular}

\section{CONCLUSION}

The HBU approach applied in this research is the best practice to determine the best use of traditional market land in urban area. This approach provides the most productive and sustainable land use warranty through five comprehensive approaches. While the traditional market still exists, the maximum productivity of the land can be achieved. The long-term goal of this research is to develop the application of adaptive and collaborative concepts on the design of spatial 
Christiono Utomo, Yani Rahmawati \& Iman Krestawan

Development of Urban Market Spatial for Highest and Best Use of Land Productivity and Sustainability

configuration and market economic value in urban areas. Future research is necessary in term of framework of methodology for value-based decision for HBU. The methodology consisted of value-based process (Utomo, Idrus, Napiah, $\&$ Khamidi, 2009) and multi-criteria decision process. A value in function/cost is the basis for the methodology. On the value-based process, HBU function and development cost of land use are analysed. On multi-criteria decision-making, a satisficing option is used by correlating the function and cost to get the value of an alternative solution. Group decision in collaborative process (Rahmawati et al., 2014) using agreement options and coalition formation is also important because of multi-stakeholders nature.

\section{ACKNOWLEDGEMENT}

The authors appreciate the recognition and awards in forms of research grant and fellowship from "Penelitian Unggulan Perguruan Tinggi (PUPT) 2017 based on contract number 563/PKS/ITS/2017"

\section{REFERENCES}

Chapin, F. S., \& Kaiser, E. J. (1979). Urban land use planning ( ${ }^{\text {rd }}$ Ed.). London: University of Illinois Press.

Grissom, T.V. (1983). The semantics debate: Highest and best use vs most probable use. The Appraisal Journal, 51(1), 45-57.

Kyle, R.C. (2005). Property Management. Chicago: Dearborn Financial Publishing.

Rahmawati, Y., Utomo, C., Anwar, N., Setijanti, P., \& Nurcahyo, C.B. (2014). An empirical model for successful collaborative design towards sustainable project development. Journal of Sustainable Development, 7(2), 1-14.

Rattermann, M. R. (2008). Highest and best use problems in market value appraisals. The Appraisal Journal, Winter, 23-25.

Reed, L., \& Kleynhans, T. (2011). The highest and best use of agricultural land in a multifunctional land market - evidence from South Africa. Journal of Modern Accounting and Auditing, 7(3), 276-288.

The Appraisal Institute (2001). The appraisal of real estate (12 $2^{\text {th }}$ Ed.). Chicago: The Appraisal Institute.

Utomo, C. Idrus, A., Napiah, M., \& Khamidi, M. F. (2009). Aggregation and coalition formation on value-based decision. Symposium on Computational Intelligence in Multi-criteria Decision-Making (MCDM). March 30-April 2, 2009, Nashville, USA.

Utomo, C., Rahmawati, Y., Suhartono, \& Negoro, N. P. (2015). A concept toward decision support for collaborative urban heritage selection. Journal of Sustainable Development, 8(8), 114-120. 